\title{
Monetary assessment of natural values - a case study from the flooded mining pit in Suszec (Poland)
}

\author{
Waldemar Szendera ${ }^{1}$, Karolina Czerwieńska², Joanna Kuczera² \\ 1Institute of Environmental Protection - National Research Institute in Warsaw, Krucza Str.5/11d, 00-548 Warsaw, Poland \\ ${ }^{2}$ Comfreylab Waldemar Szendera, Kolonia Podlesie 5, 43-267 Suszec, Poland \\ E-mail address: (corresponding author) kwszendera@poczta.onet.pl
}

\begin{abstract}
This paper presents a potential monetary assessment of natural habitats based on a method worked out in 2003 in the Czech Republic. The assessment was prepared for the reclaimed flooded mining pit in Suszec. The analysis was focused on three variants of real and potential habitats from the reclaimed land. Natural values of the flooded mining pit have undergone changes due to afforestation reclamation activities. It has been calculated that the value of natural habitats expressed in numbers will decrease by $70.7 \%$ in comparison to the area prior to reclamation, whereas the monetary value of the natural habitats will decrease by 10,319,519.00 PLN. An important element of the assessment includes recognition, diagnosis and evaluation of the actual state of natural habitats by preparing a detailed inventory and determining the most valuable species of plants and animals as well as landscape values. Unfortunately, at present in Poland there is no clear and explicit method of estimating the assessment of lost natural value that would allow approximating the monetary value of a given terrain and determine the most favourable direction of its management. Application of monetary assessment of natural habitats requires its adjustment to Polish conditions. Due to the similarity of climate and geomorphological conditions in Central Europe, it is possible to adopt elements of habitat assessments used in the Czech Republic and in Germany. Natural habitat assessment will provide a solid base for preventing conflicts caused by the needs of economic development at the expense of local protection of the natural environment. As a result, it will be easier to achieve an agreement between different parties in the investment process, and, moreover, the assessment method will prevent additional financial losses, generated during the process of achieving functionality by the habitats. Correct analysis of the values of natural habitats may significantly reduce losses in the natural environment and aid in the selection and choice of the most relevant reclamation method.
\end{abstract}

KEY WORDS: assessment, natural habitats, reclamation, mining

\section{Introduction}

The development of mining in Upper Silesia, particularly of black coal mines, has caused irreversible changes in the natural environment. Often, mining activity has been negatively perceived by the society, mainly as an activity with destructive influence on land surface, causing its subsidence and dip, destroying the soil layer, or polluting the nearby water courses. On the other hand, with time the post-mining depressions begin to fill up with water and become refugia for local populations of flora and fauna. The natural environment begins to recover and refurbish. The biodiversity and attractiveness of such localities increases. Formerly degraded lands create new possibilities for the development of many plant and animal species, whose existence was not possible in previous environments. Mining companies and local authorities are thus addressed with a crucial question: should such developed land be subject to reclamation? And if so, then should the reclamation be focused on agriculture, forestry, municipal lands or water? (OSTRĘGA \& UBERMAN, 2010; KASZTELEWICZ \& SYPNIOWSKI, 2011). The aptness of the choice depends on many factors that characterize the degraded land: previous management method, natural factors, climatic conditions, character and quality of the surrounding land, hydrological 
conditions, soil conditions, social and economic factors, technical and economic factors, costs and benefits, as well as technologies and ways of their implementation. However, ultimately it often happens that technical-economic factors have the largest influence on the range of reclamation works, instead of natural factors that do not change with time (KASZTELEWICZ \& SYPNIOWSKI, 2011). In Poland there is no clear and explicit method of assessing lost natural value, which would allow determining the monetary value of the reclaimed land, thus indicating the best direction of its management. For example, incomplete assessment of natural land in Poland can be presented for the value of natural parks, which is calculated by using the quantity and price of $1 \mathrm{~m}^{3}$ of wood. Thus, the Białowieża National Park with an area of 10,517 ha, wood supply of 4,287 thousand $\mathrm{m}^{3}$ and average wood price at 187 $\mathrm{PLN} / \mathrm{m}^{3}$, has the value of only $7.62 \mathrm{PLN} / \mathrm{m}^{2}$ (PierzchatA, 2013). However, using the method proposed by Czech scientists, the value of the Białowieża Forest calculated with the use of habitat assessment (code L8.1) is $66.87 \mathrm{PLN} / \mathrm{m}^{2}$ (SEJÁK ET AL., 2003). This value is closer to the real costs of the natural forest ecosystem. It should be thus considered what is the natural value of the land subject to reclamation and whether the assessment method reflects the actual and real costs sustained by the biogeosystem. This paper presents a method of assessing natural habitats based on the reclaimed flooded mining pit in Suszec.

\section{Study area}

The study was conducted on a reclaimed land with an area of 19.9 ha, located in the northeastern part of the Suszec community, between the Powstańców Śląskich and Na Grabówki streets, in Pszczyna County of the Silesian voivodeship. The land belongs to the Krupiński Coal Mine and has been purchased from private owners due to mining impacts. The centre of the depression is located in the valley of the Branicki Channel. The terrain is assigned to category IV of mining damage (and to a smaller degree to categories III and II). The region is covered mainly by agricultural land, objects of the technical infrastructure as well as housings and office objects. Coal exploitation has led to strong land deformations (MıŁKOWSKI, 2010; CHMiELEWSKI, 2011). A $7.5 \mathrm{~m}$ deep depression has caused changes in the directions of surface water flow and resulted in the formation of a flooding with and area of 3.8 ha and depth of $3 \mathrm{~m}$. In June 2011 reclamation works have begun aiming at the reconstruction of the degraded land by infilling the depression with waste rock (MıŁKOWSKI, 2010). The reclamation works continue till present. The area of the reclaimed flooding is outlined in red in Fig. 1.

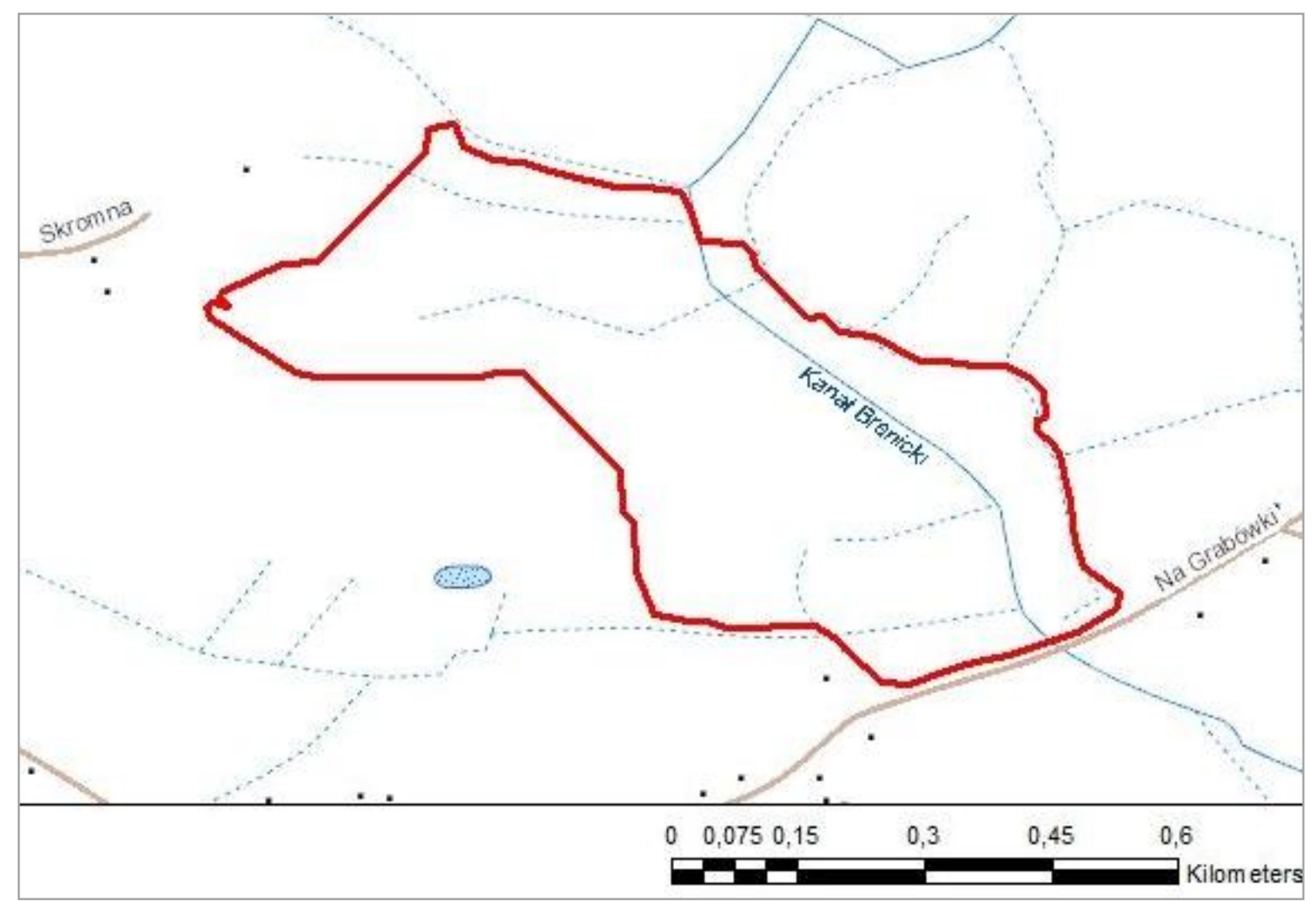

Fig. 1. Sketch-map showing the area of the reclaimed flooded mining pit (source: WMS geoportal) 


\section{Material and methods}

The method for assessing natural habitats has been worked out in 2003 in the Czech Republic and is applied during environmental decisions with regard to naturally valuable lands (SEJÁK ET AL., 2003, AGENTURA OCHRANY PŘíRODY A KRAJINY ČR). Understanding plant communities in the Czech methodology (SEJÁK, ET AL., 2003) is slightly different than in phytosociology describe in Polish methodology (MATUSZKIEWICZ, 2007). In this publication, we have made the choice of plant communities, which plant communities and plant species are similar. The method can be applied in Polish natural conditions. This is possible mainly due to the fact of similar climate, geomorphological and habitat conditions in the two countries. Successful application of the assessment method requires the preparation of a full list of natural habitats present in the region of the planned or evaluated investment (TRZĄSKI \& MANA, 2008). The assessment process comprises three stages (SEJÁK ET AL., 2003; TRZĄSKI \& MANA, 2008; CHYTRÝ ET AL., 2010): 1) recognition of natural habitats by preparation of detailed natural inventory with determination of the most precious qualities (species and habitats protected by Polish and European law); 2) determination of point value based on existing tables of algorithms; 3) calculation of monetary value with application of monetary conversion applied by the state regulatory authority. Determination of the point value for each habitat is conducted by considering eight ecological criteria for each habitat:

a. Habitat maturity - its degree of development (Z)

b. Natural character of habitat (P)

c. Structural diversity (DS)

d. Variability of species in a habitat (DD)

e. Rareness of a given habitat (VB)

f. Occurrence of rare species in a habitat (VD)

g. Habitat sensitivity - its susceptibility (CB)

h. Threat for quality and number of habitats (OB)

The first four are internal criteria, whereas the remaining are external criteria of a habitat (they determine its degree of uniqueness and susceptibility to destructive factors). Each of these properties attains a point value from 1 to 6 related to each habitat. After assigning the points for particular properties ( $\mathrm{a}-\mathrm{f})$, they should be introduced into the algorithm below, divided by value 576 (maximal number of achievable points) and multiplied by 100 :

$[(a+b+c+d) \times(e+f+g+h) / 576] \times 100=$ total points

A coefficient between 3 and 100 points per $\mathrm{m}^{2}$ is obtained for each habitat. Higher values of the coefficient indicate a more mature, natural, diversified habitat with a higher species diversity; such habitat occurs rarely, is more sensitive and more susceptible. Habitats with the highest total points are very diverse and have a high stability. The obtained point value has been multiplied according to the formula below, resulting in the monetary value of natural habitats.

Monetary value $=$ number of points $\times$ number of $\mathrm{m}^{2} \times 0.4 €$

A coefficient determined in the Czech Republic for conditions prevailing in that area was accepted in this study. 1 point corresponds to the value $0.4 €$ ( $1 €$ equals to $4.16 \mathrm{PLN}$, data from 10.12.2014) (SEJÁK ET AL., 2003; TRZĄSKI \& MANA, 2008; CHYTRÝ ET AL., 2010, AGENTURA OCHRANY PŘ́́RODY A KRAJINY ČR). Field studies leading to preparing a list of plant habitats occurring in the area of the former flooding have been conducted since 1990 .

\section{Results}

In this study an attempt was made to determine the best reclamation method in the study area. Monetary assessment was conducted for 3 variants of natural habitats:

1. Habitats that occurred prior to the reclamation process - Fig. 2;

2. Habitats presently occurring in the area - Fig. 3;

3. Habitats after completing the reclamation process - Fig. 4.

Habitats that occurred prior to the reclamation process included (Fig. 2) (SEJÁK ET AL., 2003; MATUSZKIEWICZ, 2007; CHYTRÝ ET AL., 2010):

1. Plant communities of standing waters, eutrophic to mesotrophic, hosting Littorelletea and Isoëto - Nanojuncetea (code V.1). A 2-meter littoral zone occurred around the whole flooding prior to the reclamation process. These communities encompassed $4 \%$ of the study area. Species characteristic of this habitat included: sparganium (Sparganium), calamus (Acorus calamus), spike-rush (Eleocharis palustris), brooklime (Veronica beccabunga), water forget-me-not (Myosotis scorpioides), bulrush (Typha latifolia), and floating fern (Salvinia natans). In Natura 2000 the habitat is marked with code 3130 .

2. Alternately wet/humid molinia meadows (code T1.9). This community comprised $27 \%$ of the study area. Species characteristic of this habitat included: Siberian iris (Iris sibirica), northern breadstraw (Galium boreale), water foxtail (Alopecurus geniculatus), Centaurea stoebe, spreading bellflower (Campanula patula), 
Laserpitium prutenicum, Cirsium rivulare, Cirsium palustre, and heath spotted orchid (Dactylorhiza maculata). In Natura 2000 the habitat is marked with code 6410.

3. Alluvial ash-alder forest Fraxino-Alnetum (code L2.2). This habitat covered $5 \%$ of the study area. Species characteristic of this habitat included: common alder (Alnus glutinosa), grey alder (Alnus incana), common ash (Fraxinus excelsior), white willow (Salix alba), brittle willow (Salix fragilis), silver poplar (Populus alba), black poplar (Populus nigra), and marsh marigold (Caltha palustris). In Natura 2000 the habitat is marked with code 91E0-3.

4. Transition mires and quaking bogs (usually with Scheuchzerio-Caricetea nigrae) (code R2.3). This habitat covered $3 \%$ of the study terrain. Species characteristic of this habitat included: peat moss (different species) (Sphagnum spp.), hare's-tail cottongrass (Eriophorum vaginatum), common sundew (Drosera rotundifolia), Viola uliginosa and purple marshlocks (Comarum palustre). In Natura 2000 the habitat is marked with code 7140 .

5. Lowland, extensively used hay meadows Arrhenatheretum elatioris (code T1.1). This habitat covered $35 \%$ of the study terrain. Species characteristic of this habitat included: false oat-grass (Arrhenatherum elatius), orchard grass (Dactylis glomerata), soft brome (Bromus hordeaceus), wild carrot (Daucus carota), hogweed (Heracleum sphondylium), spreading bellflower (Campanula patula), red clover (Trifolium pratense), and bird's-foot-trefoil (Lotus corniculatus). In Natura 2000 the habitat is marked with code 6510 .
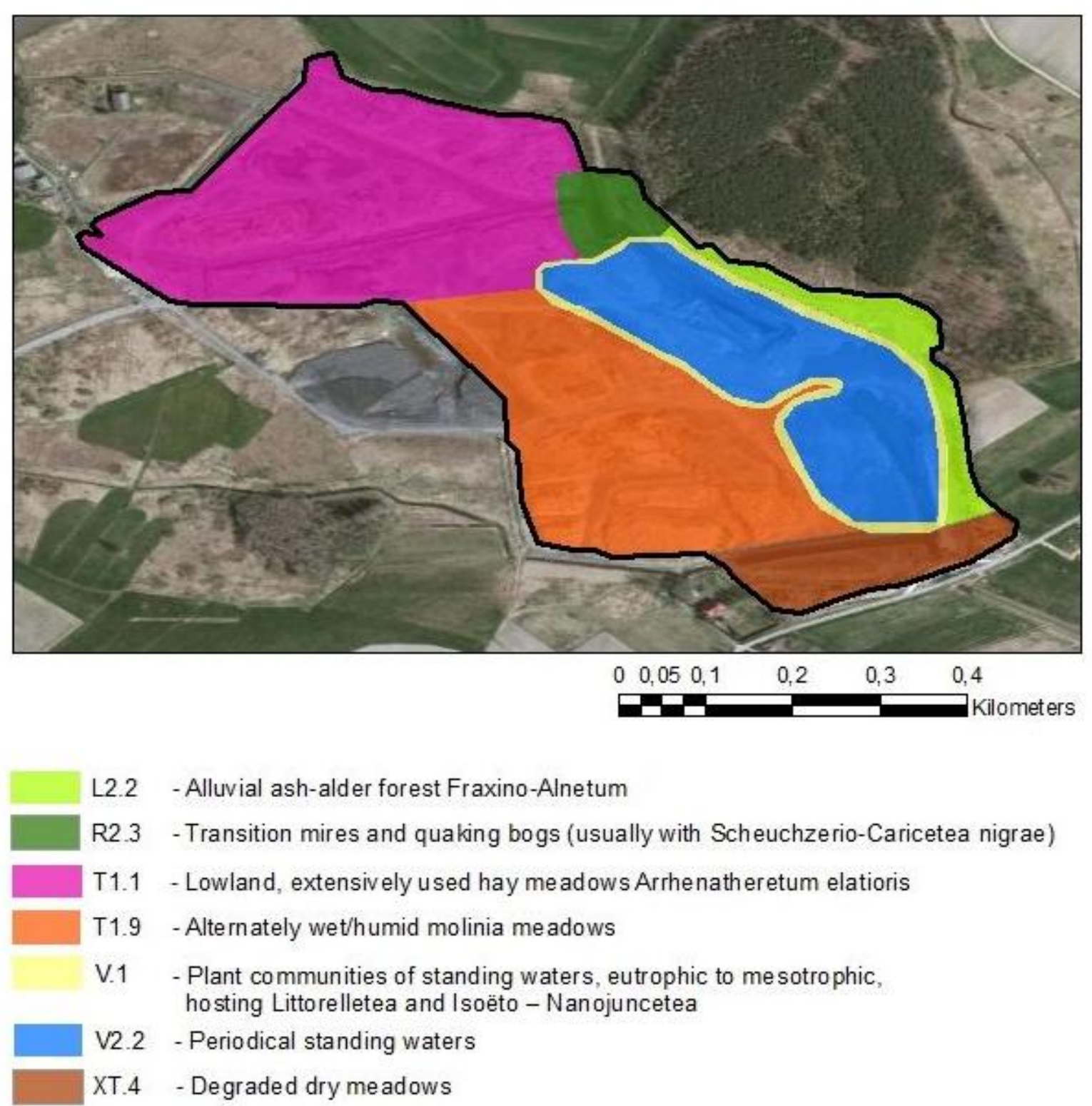

Fig. 2. Distribution of natural habitats prior to the reclamation process (source: WMS geoportal) 
6. Degraded dry meadows (code XT.4). This habitat covered $7 \%$ of the study area. The habitat served as a safety levee separating the road from the natural object, with degraded grass plants that accumulated pollution emitted nearby. Species characteristic of this habitat included: false oat-grass (Arrhenatherum elatius), orchard grass (Dactylis glomerata), and red fescue (Festuca rubra).

7. Periodical standing waters (code V2.2). This habitat covered $19 \%$ of the study area. The habitat occurred on land modified by human activity on an impermeable basement. Specific life conditions were caused by variable water levels - from momentary saturation to subsequent drying up.
Habitats that occur at present include (Fig. 3) (SEjÁK ET AL., 2003; MATUSZKIEWICZ, 2007; ChYTRÝ ET AL., 2010):

1. Degraded dry meadows (safety levee) (code XT.4). This habitat covers $7 \%$ of the study terrain. The description of the habitat is identical as in variant 1 in the case of degraded dry meadow, which occurred in the study area prior to reclamation.

2. Shrubs and perennial plants growing on degraded surfaces of non-cultivated spoil heaps and dumps (code X4.5). The habitat covers $93 \%$ of the study area. The prevailing plants include shrubs which hamper the growth of grass.
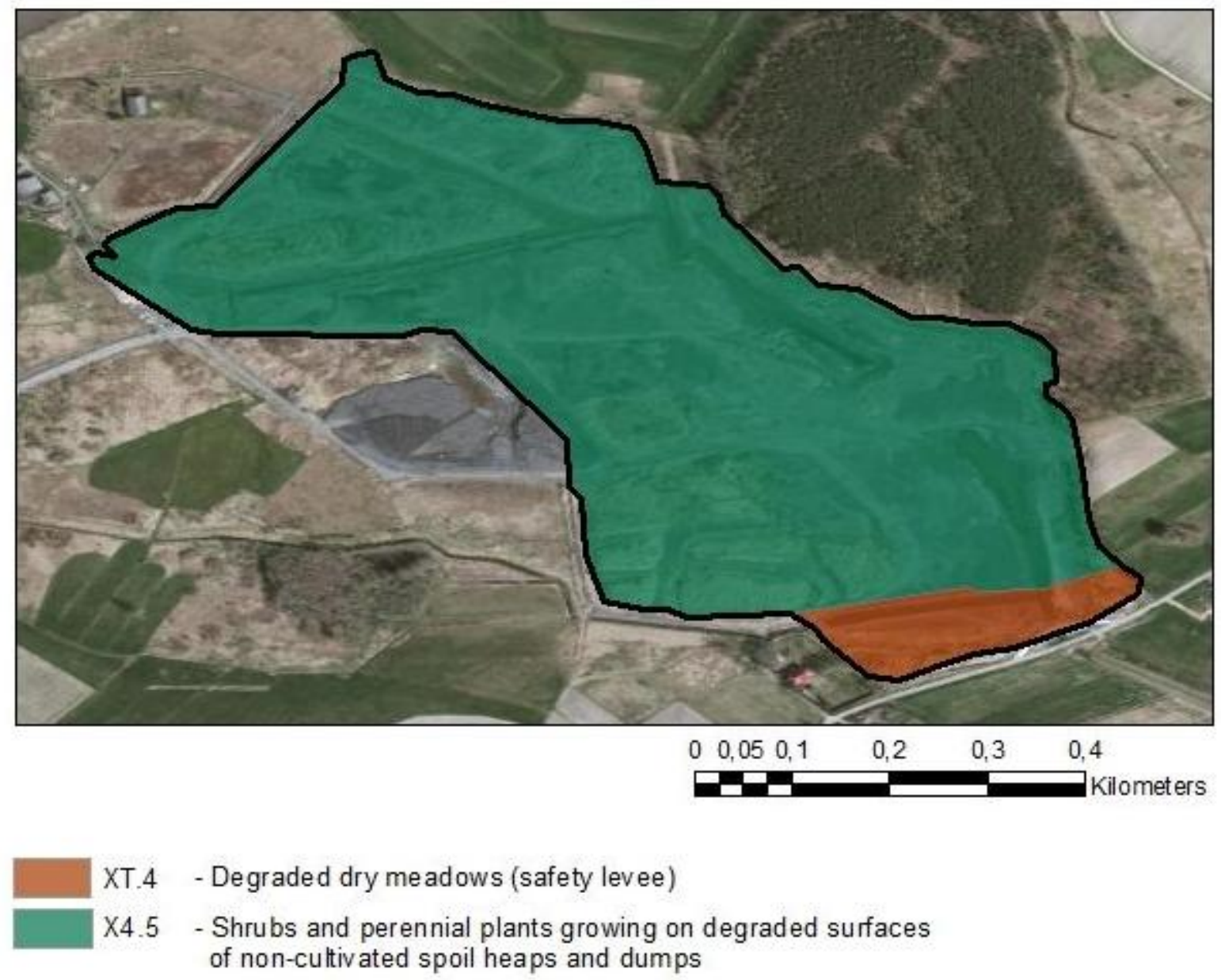

Fig. 3. Distribution of natural habitats occurring at present in the area of the flooded mining pit (source: WMS geoportal)

Habitats that will occur in the study area after the reclamation process (Fig. 4) (SEJÁK ET AL., 2003; MATUSZKIEWICZ, 2007; CHYTRÝ ET AL., 2010):

1. Degraded dry meadows (safety levee) (code XT.4). The habitat will cover $7 \%$ of the study area.

2. Plantations of forest trees (code X6.3). After reclamation the land will be covered by a forest comprising the following species: $30 \%$ Scots pine (Pinus sylvestris), 15\% English oak (Quercus robur), $15 \%$ Scots elm (Ulmus glabra) and field elm (Ulmus minor), 10\% willow (Salix sp.), 10\% common alder (Alnus glutinosa), 5\% mountain-ash (Sorbus aucuparia), 5\% Norway spruce (Picea abies), and 10\% silver birch (Betula pendula). 


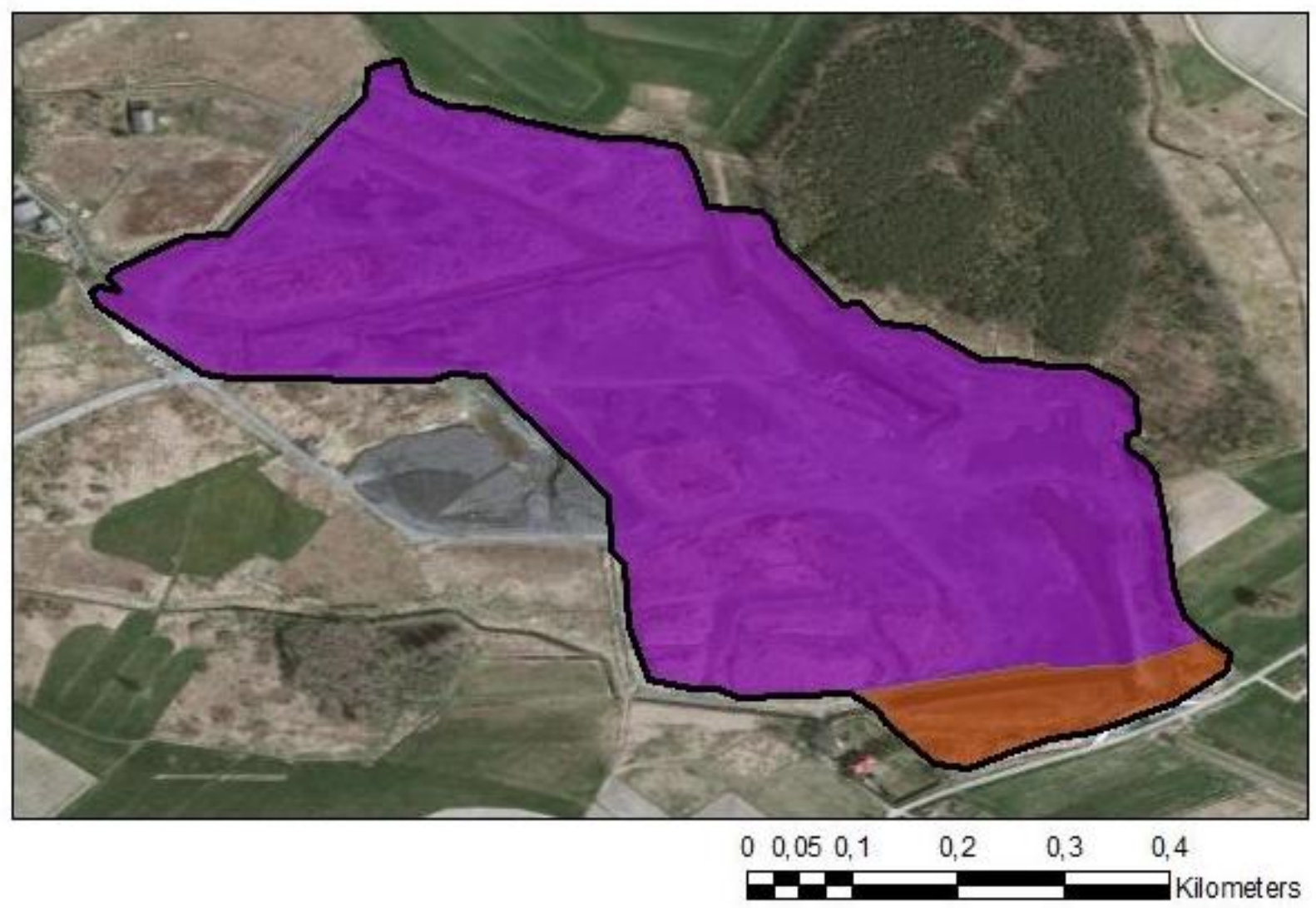

XT.4 - Degraded dry meadows (safety levee)

X6.3 - Plantations of forest trees

Fig. 4. Distribution of natural habitats after the reclamation process (source: WMS geoportal)

Table 1. Costs of land reclamation into forests

\begin{tabular}{|c|l|r|}
\hline No. & \multicolumn{1}{|c|}{ Process } & Costs [PLN] \\
\hline 1 & Cuttings & 89,869 \\
\hline 2 & Costs of planting & 185,565 \\
\hline 3 & Hydrogels & 292,265 \\
\hline 4 & Heavy equipment & $10,206,075$ \\
\hline 5 & Fertile soil & $2,783,475$ \\
\hline 6 & Grass sowing & 74,226 \\
\hline 7 & Sowing & 371,130 \\
\hline 8 & Management for 10 years & 649,478 \\
\hline 9 & Further 5 years of management & 46,391 \\
\hline & Total (sum of all costs for 15 years) & $14,698,474$ \\
\hline
\end{tabular}

A young forest grows slowly and requires a long time to attain the features of a mature forest. For the first 15 years it is in the initial state, generating high costs for the management, control and protection of young trees. The costs have been presented in Table 1 .

The total cost of land reclamation will be $14,698,474$ PLN. The costs include direct costs of the initial stage of reclamation - 14,076,831 PLN and the costs of management, control and protection of trees for the next 15 years - 695,869 PLN. It should be thus considered if forest reclamation is a costeffective process.

\section{Assessment of the monetary value of natural habitats}

As already mentioned, each habitat has points attained in each of the following categories: habitat maturity - its degree of development (Z); 
natural character of habitat $(\mathrm{P})$; structural diversity (DS); variability of species in habitat (DD); rareness of habitat (VB); occurrence of rare species in habitat (VD); habitat sensitivity - its susceptibility (CB); threat for quality and number of habitats (OB). The coefficients have been assigned from the Czech method (SEjÁK ET AL., 2003). An independent calculation has not been presented due to the fact that the Upper Silesia habitats are similar to those occurring in the Czech Republic. Table 2 presents particular points for the distinguished natural habitats, which will be taken into consideration in the assessment process in particular variants of land management.

Types of natural habitats largely depend on the plans and directions of land management.
The highest natural variability has been determined in lands not subject to reclamation (7 types of habitats). At present occur 2 types of habitats with rather low value of points per $\mathrm{m}^{2}$, i.e. XT.4 and X4.5. Unexpectedly, reclamation by afforestation will lead to impoverishment of biodiversity. Spontaneous formation of natural habitats on post-mining depressions filled with groundwater can be more favourable for the newly created natural habitats than the complex and expensive reclamation process. The most common habitat appearing in all discussed types of land management is a degraded dry meadow, with poor species composition, that forms the safety levee. Table 3 presents the area of the distinguished natural habitats.

Table 2. Points for selected natural habitats (after Seják et al., 2003)

\begin{tabular}{|c|c|c|c|c|c|c|c|c|c|}
\hline Habitat & Z & P & DS & DD & VB & VD & CB & OB & Habitat value in points $/ \mathrm{m}^{2}$ \\
\hline V.1 & 5 & 5 & 4 & 4 & 4 & 4 & 4 & 3 & 47 \\
\hline T1.9 & 5 & 5 & 4 & 5 & 4 & 5 & 5 & 5 & 63 \\
\hline L2.2 & 4 & 6 & 6 & 6 & 2 & 3 & 3 & 3 & 42 \\
\hline R2.3 & 5 & 6 & 4 & 4 & 4 & 4 & 5 & 4 & 56 \\
\hline T1.1 & 3 & 4 & 4 & 5 & 2 & 3 & 4 & 3 & 33 \\
\hline XT.4 & 3 & 3 & 3 & 3 & 2 & 2 & 2 & 3 & 19 \\
\hline X4.5 & 1 & 1 & 3 & 2 & 3 & 1 & 2 & 2 & 10 \\
\hline X6.3 & 1 & 2 & 2 & 3 & 4 & 1 & 1 & 3 & 13 \\
\hline V2.2 & 5 & 6 & 3 & 3 & 4 & 2 & 5 & 4 & 44 \\
\hline
\end{tabular}

Table 3. Area of the distinguished natural habitats

\begin{tabular}{|c|r|r|c|}
\hline Habitat type & $\begin{array}{c}\text { Area prior to reclamation } \\
\left(\mathrm{m}^{2}\right)\end{array}$ & $\begin{array}{c}\text { Present area } \\
\left(\mathrm{m}^{2}\right)\end{array}$ & $\begin{array}{c}\text { Area of the created habitats } \\
\left(\mathrm{m}^{2}\right)\end{array}$ \\
\hline V.1 & 8,696 & 0 & 0 \\
\hline T1.9 & 53,779 & 0 & 0 \\
\hline L2.2 & 9,835 & 0 & 0 \\
\hline R2.3 & 5,973 & 0 & 0 \\
\hline T1.1 & 68,989 & 13,187 & 13,187 \\
\hline XT.4 & 13,187 & 185,565 & 0 \\
\hline X4.5 & 0 & 0 & 185,565 \\
\hline X6.3 & 0 & 0 & 0 \\
\hline V2.2 & 38,293 & 198,752 & 198,752 \\
\hline Total: & 198,752 & 0 & 0 \\
\hline
\end{tabular}

The point value for each natural habitat was calculated for three variants based on particular points obtained by multiplying them by the area of each habitat. Prior to reclamation, the point value was $8,768,453$ points $/ \mathrm{m}^{2}$, at present the value is $2,051,360$ points $/ \mathrm{m}^{2}$, whereas the newly created habitat will have $2,566,819$ points $/ \mathrm{m}^{2}$ (Tab. 4). Therefore the highest point value for habitats was obtained for the study area prior to the reclamation process, and the lowest - for the present habitats. Thus, the point value of the study area decreased by $76.6 \%$. In the variant when the degraded land would be subject to reclamation into a forest, the point value of the land would decrease by $70.7 \%$. The reason for such drastic change of point value is the disappearance of some 
natural habitats and the isolation of anthropogenic plant communities with ruderal species decreasing the land value. Transformation of the degraded land into plantations of forest trees will also not contribute to the increase of the point value of the habitat.

The monetary value of natural habitats was obtained by multiplying the point values for particular habitats by the conversion rate with the value of 1.66 PLN per $1 \mathrm{~m}^{2}$ (Tab. 5). According to the assumptions of the Czech method of habitat assessment, the value of the drowned mining pit prior to reclamation would be $14,590,705.00$ PLN.
The monetary value of the present habitat is $3,413,464.00$ PLN, whereas the monetary value of the habitat reclaimed into a forest would be $4,271,186.00$ PLN. The loss of valuable habitats caused by initiating the reclamation process corresponds to the potential loss of $11,177,241.00$ PLN. Completing the reclamation process through afforestation of the terrain will result in increase of the monetary value by only $857,722.00$ PLN. The Czech method does not take into consideration additional costs during the reclamation process and costs of maintaining the forest. This state is illustrated in Fig. 5.

Table 4. Point values for particular habitats

\begin{tabular}{|c|c|c|c|c|}
\hline $\begin{array}{c}\text { Habitat } \\
\text { type }\end{array}$ & Points $/ \mathrm{m}^{2}$ & $\begin{array}{c}\text { Point values - } \\
\text { habitats prior to reclamation }\end{array}$ & $\begin{array}{c}\text { Point values - } \\
\text { present habitats }\end{array}$ & $\begin{array}{c}\text { Point values - } \\
\text { developing habitats }\end{array}$ \\
\hline V.1 & 47 & 407,625 & 0 & 0 \\
\hline T1.9 & 63 & $3,370,524$ & 0 & 0 \\
\hline L2.2 & 42 & 413,207 & 0 & 0 \\
\hline R2.3 & 56 & 334,944 & 0 & 0 \\
\hline T1.1 & 33 & $2,299,633$ & 247,256 & 0 \\
\hline XT.4 & 19 & 247,256 & $1,804,104$ & 0 \\
\hline X4.5 & 10 & 0 & 0 & $2,319,563$ \\
\hline X6.3 & 13 & 0 & 0 & 0 \\
\hline V2.2 & 44 & $1,695,263$ & $2,051,360$ & 0 \\
\hline Total: & & $8,768,453$ & $0,566,819$ \\
\hline
\end{tabular}

Table 5. Monetary values for particular habitats

\begin{tabular}{|c|r|r|c|}
\hline $\begin{array}{c}\text { Habitat } \\
\text { type }\end{array}$ & $\begin{array}{c}\text { Monetary value of habitats } \\
\text { prior to reclamation [PLN] }\end{array}$ & $\begin{array}{c}\text { Monetary value - } \\
\text { present habitats [PLN] }\end{array}$ & $\begin{array}{c}\text { Monetary value - } \\
\text { developing habitats [PLN] }\end{array}$ \\
\hline V.1 & 678,288 & 0 & 0 \\
\hline T1.9 & $5,608,552$ & 0 & 0 \\
\hline L2.2 & 687,576 & 0 & 0 \\
\hline R2.3 & 557,347 & 0 & 0 \\
\hline T1.1 & $3,826,590$ & 0 & 011,434 \\
\hline XT.4 & 411,434 & 411,434 & 0 \\
\hline X4.5 & 0 & $3,002,029$ & 0 \\
\hline X6.3 & 0 & 0 & $3,859,752$ \\
\hline V2.2 & $2,820,918$ & 0 & $0,271,186$ \\
\hline Total: & $14,590,705$ & $3,413,464$ & 0 \\
\hline
\end{tabular}

\section{Conclusions}

The conducted analysis of monetary assessment of natural habitats according to the methodology worked out in the Czech Republic allows for a significant decrease of losses in the natural environment by coherent and responsible choice of reclamation directions for degraded land. It indicates which activity is profitable in terms of economy and in accordance with environment protection requirements. It is thus a correct tool to be used when making crucial decisions in the investment process, not only on a local but particularly on a state level. The method allows comparing economic factors and natural environmental aspects. Assessing the lost monetary value of the natural environment is comprehensible for the local community and favours working out suitable technical solutions by investors and local environmental authorities in order to preserve natural habitats. 


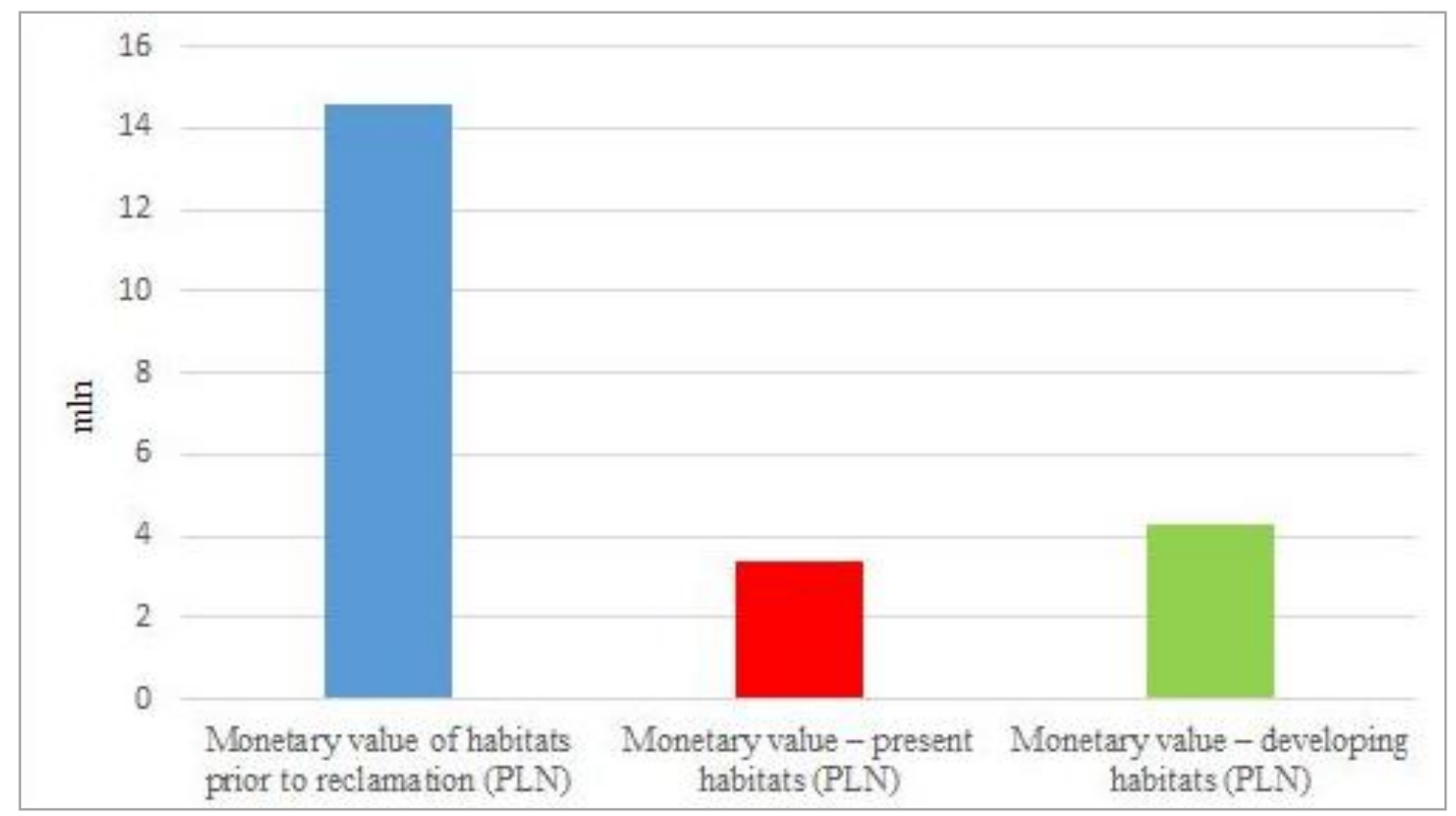

Fig. 5. Monetary values for particular habitats

The results obtained for the flooded mining pit in Suszec explicitly show that leaving the land to natural changes and not undertaking the reclamation process would be better and economically more feasible than afforesting the land and maintaining the forest for the next 15 years. It is thus important for appropriate experts and institutions linked with environmental protection to work out a Polish method of assessing natural habitats, based on solutions accepted in the Czech method. This method should be implemented into Polish law and become a tool used by all parties making crucial environmental decisions in the investment process.

\section{References}

Agentura ochrany př́rody a krajiny ČR: http://www. biomonitoring.cz/biotop_cerv_kn/texty/8/index.html

Chmielewski W. 2011. Studium uwarunkowań i kierunków zagospodarowania przestrzennego gminy Suszec, Część A Uwarunkowania rozwoju, Prac. Urban. w Rybniku Sp. z o.o., Rybnik.
Chytrý M., Kučera T., Kočí M., Grulich V. \& Lustyk P. 2010. Katalog biotopů České republiky. Ed. 2. Agentura ochrany př́rody a krajiny ČR, Praha.

Kasztelewicz Z., Sypniowski S. 2011. Kierunki rekultywacji w polskich kopalniach węgla brunatnego na wybranych przykładach. Górn. i Geoinż., 35, 3: 119-131.

Matuszkiewicz W. 2007. Identification handbook for plant communities (in Polish: Przewodnik do oznaczania zbiorowisk roślinnych Polski). Ser. Vademecum geobotanicum. PWN, Warszawa.

Miłkowski T. 2010. Prognoza oddziaływania na środowisko studium uwarunkowań i zagospodarowania przestrzennego gminy Suszec, II Edycja, Prac. Urban. w Rybniku Sp. z o.o., Rybnik.

Ostręga A., Uberman R. 2010. Kierunki rekultywacji i zagospodarowania - sposób wyboru, klasyfikacja i przykłady. Górn. i Geoinż., 34, 4: 445-461.

Pierzchała Ł. 2013. Ochrona przyrody a rozwój gospodarczy konflikty i zbieżności (wycena siedlisk przyrodniczych), GIG, Katowice, dn. 15.02. 2013 r. [PowerPoint presentation], http://www.azr.gig.eu/node/9.

Seják J., Dejmal I. \& kol. 2003. Hodnocení a oceňování biotopů $\check{C} R$. Český ekologický ústav, Praha.

Trząski L., Mana V. 2008. Monetary value assessment of biotopes in the Borek river valley, Sosnowiec - a methodology proposal for Poland. Research reports mining and environ., 3: 79-90. 